\section{American science}

\section{Supply-siders now}

\section{Washington}

"We are now forging a substantially closer relationship with both the legislative and executive branches of Congress", the retiring president of the American Association for the Advancement of Science (AAAS), Dr Alan Bromley of Yale University, said on the opening day of the association's annual meeting in Washington on Monday.

Dr Bromley listed various ways in which AAAS was exercising what he described as a "service role" for private and public science decision-makers. Such activities range from providing testimony to congressional hearings to preparing regular and widely quoted assessments of the impact of federal policy on the size of the US research and development effort.

But if a considerable amount of AAAS's time is now spent helping the government to do its job, there has also been an expansion of effort to compensate for federal actions - for example, the cutting back of support for science education in schools.

Following up an initiative launched at last year's annual meeting in Toronto, the chairman of the AAAS board of directors,
Dr Frederick Mosteller, announced that the association had just received a $\$ 6.5$ million grant from Philips Petroleum for a series of television films to complement the work of mathematics teachers in public schools "by making mathematics more lively and significant".

Another educational initiative is the publication of a set of science teacher notes based on articles appearing in AAAS's monthly science magazine Science 82 . The association is also convening two conferences later this year with leaders of various scientific and technical societies, the first dealing with urgent policy issues in science education, the second concentrating on the growing shortage of science and mathematics teachers.

Inevitably, a prominent theme of this year's meeting is the impact of the Reagan Administration's cuts in public spending on scientific research. In an address on Sunday evening, the President's Science Advisor, Dr George (Jay) Keyworth, emphasized again the Administration's awareness of the importance of basic science, promising that the next "budget submission will clearly reflect that".

$\mathrm{He}$ also again warned that there were hard choices to be made. In the short term, there was general acceptance at the meeting that such a policy was appropriate. Dr Bromley pointed to the Department of

\title{
UK director for US Biogen laboratory
}

Dr Richard Flavell, one of Britain's whizz-kids of gene cloning, is to leave the country to become research director of Biogen Inc., the American arm of the international biotechnology firm, Biogen NV.

Flavell is currently leader of the only gene cloning group at the National Institute of Medical Research (NIMR), Mill Hill, London, one of the two principal laboratories of the UK Medical Research Council. Gene cloning is also done at other laboratories of the council - notably at Hills Road, Cambridge - but there is a strong feeling that application of the technique, central now to the whole of molecular biology, should be more in Britain. The loss of Dr Flavell is thus significant, particularly at a time when NIMR is seeking a new director and reconsidering its role within British biology.

In fact, Flawell has officially been granted "leave of absence" from Mill Hill for two years; but it seems unlikely that two years hence Flavell will want to leave Cambridge, Massachusetts, where the Biogen laboratory is being set up.

Flavell will continue to direct a group at Mill Hill, if at a distance, but he wishes to take some of the more fashionable work with him. He expects that half-a-dozen of his Mill Hill team will go with him to Biogen, taking with them expertise on the $\mathrm{H}-2$ regions of the mouse genome. These regions code for histocompatibility antigens in the mouse, and it may be speculated that Biogen will now take an interest in the generation of reagents for tissue-typing in man, using the equivalent human HLA regions. Flavell will leave at Mill Hill the part of his group which deals with the globin genes, also important in immunology but less at the centre of attention now than H-2 and HLA.

At Biogen, Flavell will take over a fledgling staff of 20 scientists, which he will increase to 75 by the end of 1982 . He will, of course, be concerned mostly with fostering the commercial interests of Biogen through research, but has been guaranteed the opportunity to pursue his own basic research - largely through the Mill Hill team he takes with him.

Flavell cannot say yet what the research interests of his new laboratory will be; but according to Professor Charles Weissmann of Zurich, who is chairman of the scientific council of Biogen, the Cambridge laboratory was originally planned to pay closer attention to the chemical and processing aspects of biotechnology than Biogen's Geneva laboratory which was founded earlier (see Nature 27 October 1981, p.599). Whether Flavell will in fact follow this line is open to question.
Energy's High Energy Physics Advisory Board and the Nuclear Science Advisory Committee as examples of ways that scientists in a particular fields, when finances get tight, have been able to determine their own scientific priorities.

But in the longer term, it was said, repeated budget cuts will be severely disruptive. Figures produced by AAAS itself last week showed that for the twoyear period 1981-82, the result of federal actions will be to reduce the civilian research and development budget by about 16 per cent in real terms (constant dollars), with a 22.2 per cent growth in the military research and development budget over this period.

Another issue being hotly debated in the meeting rooms and corridors is the current dispute about creationism and the teaching of evolutionary theory in public schools. On Monday morning, the AAAS board unanimously passed a resolution that "creationist groups are imposing beliefs disguised as science upon teachers and students to the detriment and distortion of public education in the United States".

Registration at the 1982 meeting is expected to be about 5,000 which AAAS officials say is approximately the same as the last time the association held its annual meeting in Washington three years ago. Next year, in Detroit, they are hoping for something better, by moving the timing of the meeting from January to May.

That decision has been partly determined by the weather. During last year's meeting, Toronto experienced its coldest winters for almost a century, with temperatures of $-30^{\circ} \mathrm{C}$. The previous year, San Francisco airport had been closed by fog.

David Dickson

\section{Biomedical research NIH takes a cut}

\section{Washington}

The National Institutes of Health (NIH) told recipients of biomedical research grants and contracts last week that new and continuation grant awards made in the next three months are likely to be 4 per cent lower than initially proposed by President Reagan in his budget request to Congress last March.

It could have been worse. A revised budget request, issued in September, demanded a further 12 per cent reduction in all discretionary public spending and many federal agencies have had their activities curtailed significantly in the drive to reduce the federal deficit. As it is the NIH budget for 1982 - the fiscal year which started last October - will only increase by 2.2 per cent, considerably less than the current rate of inflation, and the first significant drop in real terms for federal support of biomedical research since the mid-1970s.

However, in the short term, no major damage seems to have been inflicted, and 
NIH's budget strategy of attempting to stabilize the number of new and renewing competitive awards at about 5,000 remains virtually intact. Furthermore, Congress has replaced much of the money for research training grants which the Office of Management and Budget wished to cut.

Technically, the 4 per cent reduction is only a provisional figure, valid up to March. Unable to agree on a detailed appropriations bill, Congress agreed last month to a "continuing resolution"' for the next three months. In practice, however, since debate on the budget for the 1983 fiscal year begins later in January - and no substantial objection to the provisional 1982 totals are expected from the White House - the 4 per cent reduction is likely to run to September.

It has been a confused budget year for NIH. Before leaving office in January, President Carter proposed a biomedical budget for the institutes of $\$ 3,770$ million, a figure left virtually untouched in the Reagan Administration's budget review in March and representing an increase of about 5.6 per cent over 1981 . However, realizing that the budget deficit in general was going to be much larger than initially anticipated, the Reagan Administration in September recommended an across-theboard cut of 12 per cent, which would have reduced the NIH budget to $\$ 3,310$ million.

The net result of last month's continuing resolution is that, rather than having to reduce the number of new awards for competing research projects to 4,230 , as the proposed September revisions would have required, NIH expects to be able to make almost 4,800 of these during the current financial year. This is little short of the 5,000 which was adopted as a goal two years ago, following several years in which the number of such awards, which are provided to support investigator-initiated research projects, had fluctuated widely.

The budget resolution procedure thwarted a move supported by several legislators in the House of Representatives to direct additional research funds to three institutes: the National Institute of General Medical Sciences, the National Institute of Allergy and Infectious Diseases, and the National Institute of Child Health and Human Development. These were felt to be suffering more than the others from the squeeze on research funds, in terms of the quality of the research projects that were being refused funding.

NIH officials are optimistic that the 1983 budget which $\mathrm{Mr}$ Reagan submits to Congress next month will again contain a small increase for NIH. Secretary of Health Mr Richard Schweiker is said to have argued successfully against major cuts in biomedical research that had been proposed by the Office of Management and Budget.

David Dickson

\section{New director chosen for NIH}

\section{Washington}

Dr James B. Wyngaarden, chairman of the department of medicine at Duke University in North Carolina, is expected to be nominated by President Ronald Reagan as the new director of the US National Institutes of Health (NIH) in Bethesda, Maryland.

Although yet to be formally announced - and subject to approval by the US Senate - Dr Wyngaarden's appointment is thought to have been unofficially approved by the White House, and the delay in making an announcement is the result of the lengthy security and financial checks which all presidential appointees undergo.

Dr Wyngaarden would probably be a popular choice at NIH's headquarters, and with the biomedical research community in general. Those who know him say they expect him to provide strong leadership and vigorously to defend the $\$ 3,600$ million research budget of NIH, the principal source of federal funding for biomedical research in the United States.

Dr Wyngaarden has been a close professional colleague of $\mathrm{Dr}$ Donald Fredrickson, who resigned as $\mathrm{NIH}$ director last July after six years in the post. Together with Dr John B. Stanbury, the three were co-editors of an influential collection of essays, The

Metabolic Basis of Human Diseases. First published in 1960, the book is about to go into its fifth edition, and is considered by many to be a classic in its field.

Dr Fredrickson said last week that he had "no doubt" that Dr Wyngaarden would fill the NIH position extremely well. "He is a good physician, an excellent scientist, and understands the institutional aspects of medical research very well; I have every confidence that he will be an excellent director'.

A graduate of the University of Michigan, Dr Wyngaarden is no stranger to Washington science policy circles. He was a consultant to the Office of Science and Technology Policy between 1966 and 1972, and a member of the President's Science Advisory Committee from 1972 until its abolition in 1973. Before his appointment at Duke, he was professor of medicine and chairman of the department at the University of Pennsylvania from 1965 to 1967.

NIH scientists hope that a speedy confirmation of Dr Wyngaarden's appointment will help to accelerate other senior appointments at NIH. Six of the twelve institutes lack a permanent director, and approving the new appointments will be one of the first tasks awaiting the new director.

David Dickson

\section{Molecular biology Trimming costs}

Molecular biologists who are used to relying on the European Molecular Biology Organisation for providing fellowships and other useful means of mobility within Europe may have to pay closer attention to the politics of its budget next December for the 1982 budget has seen a 3 per cent fall (in real terms) for the second year running.

The secretary of the organization, Dr John Tooze, says that management costs have been trimmed to the absolute minimum, and that for 1982 cuts will have to be undertaken in the EMBO programme itself. The 1982 budget will be DM 3.5 million $(£ 825,000)$, numerically 8 per cent above last year but 3 per cent below EMBO's calculated inflation figure.

The EMBO scheme accounts for $\mathbf{4 0 0}$ fellowships in any year, plus 40 courses and workshops and a small lectureship programme - which often takes prominent American and other visiting scientists around Europe on a lecture tour. It is this lecture programme which is likely to be cut this year.

If the budget were to be cut again for a third year, the fellowships and workshops would be hit, says Tooze. Then the smaller countries (of the 17 member states of EMBO) would certainly object. These countries are probably the main beneficiaries of the programme, and they in fact constitute a two-thirds majority of states on the council which votes the budget of EMBO each year. Decisions can be taken by such a majority but the remaining states - Britain, France, Germany and Italy contribute nearly 60 per cent of the budget. The danger is that if the small countries kick up a fuss, the big four could refuse to pay. This year a compromise has been reached. It may not be so easy next year.

Robert Walgate

\section{Microbial collections \\ Bugs in hazard}

Once again, a British microbial culture collection is threatened by lack of funds. At the end of last year the Ministry of Agriculture, Fisheries and Food announced its intention to withdraw support for the National Collection of Industrial Bacteria housed at the Torry Research Station in Aberdeen. This is the third time in two years that culture collections have been threatened by withdrawal of funds. The Brewery Research Foundation and the agriculture ministry have already stopped supporting the national yeast culture collection and the Commonwealth Mycological Institute and Natural Environment Research Council have said that they wish to cut support for the national fungi collection.

Although the problems of the yeast and fungal collections have been at least 